\title{
IMPLEMENTASI KETERAMPILAN DASAR KONSELING DALAM \\ LAYANAN KONSELING INDIVIDUAL DI SMK NEGERI 1 KEMLAGI MOJOKERTO
}

\author{
Ayong Lianawati \\ Dosen Program Studi Bimbingan dan Konseling \\ FKIP Universitas PGRI Adi Buana Surabaya \\ Email: ayong@unipasby.ac.id
}

\begin{abstract}
ABSTRAK
Konseling individual merupakan suatu proses pemberian bantuan secara profesional untuk memfasilitasi konseli dalam menyelesaikan permasalahannya. Dalam layanan konseling tentunya konselor sebagai fasilitator dituntut untuk mempunyai seperangkat keterampilan dasar konseling sebagai modal utama dalam memberikan layanan bimbingan dan konseling. Tujuan penelitian ini adalah untuk mengetahui bagaimana implementasi keterampilan konseling dalam layanan konseling individual di SMK 1 Kemlagi Mojokerto. Metode yang digunakan dalam penelitian adalah deskriptif kualitatif. Subjek dalam penelitian ini adalah konselor sekolah. Penelitian ini menitikberatkan pada implementasi dan keterampilan dasar konseling.
\end{abstract}

Kata Kunci: Konseling individual, keterampilan konseling. 


\section{PENDAHULUAN}

Layanan bimbingan dan konseling merupakan bagian yang penting dalam pelaksanaan program pendidikan. Salah satu tujuan utama layanan bimbingan dan konseling adalah membentuk siswa menjadi individu yang berkembang optimal, produktif dan berbudaya. Prinsip bimbingan dan konseling adalah "Guidance for All”, artinya individu memiliki hak yang sama dalam mendapatkan layanan bimbingan dan konseling, siapa pun individu itu, dari mana pun individu itu berasal, dan bagaimana pun kondisi individu itu memiliki hak yang sama dalam mendapatkan pelayanan (Nurihsan \& Yusuf, 2009: 17).

Salah satu layanan yang ada dalam bimbingan dan konseling adalah layanan konseling individual. Konseling merupakan suatu layanan yang bersifat kuratif dan banyak menggunakan keterampilan dan teknik dalam membantu konselinya dalam menyelesaikan masalahnya. Menurut ASCA makna konseling adalah hubungan tatap muka yang bersifat rahasia, penuh dengan sikap penerimaan dan pemberian kesempatan dari konselor kepada konseli, konselor mempergunakan pengetahuan dan keterampilannya untuk membantu konselinya dalam mengatasi masalahnya (Yusuf, 2009: 44).

Dalam layanan bimbingan dan konseling, konselor memiliki peran utama dan signifikan atas keberhasilan layanan bimbingan dan konseling. Konselor mempunyai tugas dan tanggungjawab terhadap peningkatan mutu dan pembaharuan kompetensi konselor yang menjadi suatu bagian pasti dalam perkembangan dan kompleksitas permasalahan yang ditangani oleh layanan bimbingan dan konseling di sekolah. Semakin pesatnya perkembangan penyebaran informasi, kondisi ini melahirkan karakteristik yang berbeda pada setiap siswa dan selanjutnya menuntut konselor untuk memiliki kompetensi dalam menggunakan keterampilan konseling pada pelaksanaan layanan konseling.

Hartono dan Soedarmadji (2013:57) menyatakan bahwa seorang konselor sebagai tenaga profesional harus memiliki 
keterampilan (skill) yang memadai dalam memberikan layanan konseling. Keterampilan yang harus dimiliki seorang konselor adalah memiliki keterampilan dalam melaksanakan sebuah proses konseling dari awal sampai akhir.

Fenomena yang terjadi dilapangan menunjukkan bahwa konselor masih belum sepenuhnya menggunakan keterampilan konseling dalam layanan konseling individual. Hal tersebut senada dengan hasil penelitian Kusmaryani (2010) tentang

penguasaan keterampilan konseling guru pendamping (koselor) sekolah di Yogyakarta yang menunjukkan bahwa dalam pelaksanaan konseling selama ini hanya sebagian konselor (47\%) yang telah menggunakan keterampilan konseling secara optimal, sebagian konselor (53\%) belum dapat menggunakan keterampilan konseling secara optimal.

Jika fenomena tersebut dibiarkan dan tidak mendapat perhatian khusus maka akan berdampak negatif. Salah satu dampaknya adalah berkurangnya minat siswa terhadap layanan konseling individual karena siswa mempersepsikan layanan konseling hanya sebatas curhat dan pemberian nasihat semata. Tingginya minat siswa terhadap layanan konseling individual setidaknya dipengaruhi oleh optimalnya konselor dalam menggunakan keterampilan konseling. Sejalan dengan hal tersebut, hasil penelitian Mahadhita (2015) menunjukkan bahwa terdapat hubungan yang signifikan antara keterampilan dasar konseling dengan minat siswa mengikuti layanan konseling individual di SMA Negeri 1 Godong tahun pelajaran 2014/2015.

Kurang optimalnya konselor menggunakan keterampilan konseling dalam layanan konseling individual tentu adanya faktor yang mendasari. Kusmaryani (2010) menyebutkan beberapa faktor penghambat dalam menggunakan keterampilan konseling antara lain: (1) waktu yang sempit, pengalaman yang kurang, (3) belum menguasai dengan optimal, (4) kurangnya pemahaman tentang keterampilan konseling, (5) tidak dapat berempati-masuk dengan perasaan konseli, dan (6) suasana yang tidak memungkinkan, (7) faktor 
lingkungan (ruang konseling tidak memadai), (8) banyaknya hal dari konseli yang perlu diungkap dan (9) kurangnya pemahaman dan pelatihan.

Dengan demikian dapat dikatakan bahwa, salah satu faktor yang melatarbelakangi kegagalan dalam pelaksanaan layanan konseling individual dalam mencapai tujuan yang diharapkan adalah kurang optimalnya konselor dalam menggunakan keterampilanketerampilan konseling.

\section{METODE PENELITIAN}

Penelitian ini menggunakan pendekatan kualitatif. Teknik pengumpulan data dilakukan dengan triangulasi (gabungan) analisis data yang bersifat kualitatif. Jenis penelitian ini adalah deskriptif kualitatif yang bertujuan menganalisis tentang implementasi keterampilan konseling dalam layanan konseling Individual di SMK 1 Kemlagi Mojokerto.

Penelitian dilakukan di SMK 1 Kemlagi Mojokerto. Subjek dalam penelitian adalah konselor di sekolah tersebut.
Penelitian dilakukan berdasarkan tiga tahapan utama yakni persiapan, pelaksanaan, dan analisis data. (1) pada tahap persiapan peneliti melakukan studi pendahuluan untuk mengidentifikasi masalah layanan Bimbingan dan Konselig, melakukan pengkajian berbagai literatur pendukung yang terkait dengan penelitian, menentukan subjek penelitian, merancang instrumen penelitian yang berupa pedoman observasi dan daftar pertanyaan wawancara, dan melakukan validasi instrumen. (2) tahap pelaksanaan. Pada tahap ini, peneliti melakukan observasi dengan cara melakukan pengamatan langsung mengenai pelaksanaan layanan konseling individual yang dilaksanakan oleh konselor di SMK 1 Kemlagi Mojokerto, melakukan wawancara langsung kepada konselor mengenai keterampilan dan proses layanan konseling individual. (3) tahap analisis data. Pada tahap ini peneliti melakukan analisis dan memadukan seluruh informasi yang telah diperoleh pada saat observasi dan wawancara kepada konselor selanjutnya dilakukan penarikan 
kesimpulan setelah analisis data.

Penarikan kesimpulan bertujuan untuk merumuskan apakah konselor dalam pelaksanaan layanan konseling individual telah mampu mengimplementasikan keterampilanketerampilan konseling dengan baik.

\section{PEMBAHASAN}

Hasil pedoman observasi dan wawancara dapat diambil sebuah kesimpulan sebagai berikut, observasi yang dilakukan pada keterampilan konselor dalam melakukan layanan konseling individual pada siswa ketika di sekolah menunjukkan bahwa konselor di SMK 1 Kemlagi perlu meningkatkan keterampilanketerampilan konseling dalam implementasi layanan konseling individual. Hal ini dapat dilihat dari beberapa aspek pengamatan yang dilakukan. Dilihat dari latar belakang pendidikannya, 3 dari 5 konselor di sekolah adalah lulusan bimbingan dan konseling, sehingga dalam layanan konseling, konselor yang berlatar belakang BK sudah menggunakan keterampilanketerampilan konseling tapi belum secara maksimal.
Keterampilan konselor dalam melakukan konseling individual sudah cukup baik. Akan tetapi masih perlu perbaikan dalam layanan konseling. Hal ini terlihat dari hasil pengamatan yang dilakukan ketika proses konseling inidvidual berlangsung. Pengamatan dilakukan dari mulai tahap attending yang menunjukkan bahwa tahapan ini dilakukan dengan sangat singkat tanpa melakukan runtutan kegiatan attending dengan tepat sehingga proses konseling hampir seperti panggilan pada siswa yang bermasalah. Ketika mulai memasuki kegiatan inti konseling, konselor jarang sekali atau bahkan tidak melakukan parafrase, tapi konselor lebih banyak menggunakan keterampilan bertanya tentang permasalahan yang dialami konseli. Saat konseli menceritakan masalahnya, konselor telah menggunakan keterampilan merefleksikan isi tapi kurang dalam merefleksikan perasaan.

Pada sesi konseling, konselor mampu menjadi pendengar yang baik dan memahami permasalahan konseli. Saat memasuki tahapan implementasi 
strategi, konselor kurang dapat menggunakan strategi konseling dengan baik. Konselor lebih banyak menggunakan saran sebagai seorang guru agar konseli dapat segera menyelesaikan masalahnya. Pada tahap pengakhiran, konselor hanya melakukan secara sederhana tanpa melakukan evaluasi, menyimpulkan dan melakukan follow up pada konseli.

Selain dari sisi layanan konseling, observasi yang dilakukan oleh peneliti juga melihat dari sisi intensitas pelaksanaan layanan konseling individual yang dilakukan di sekolah. Konseling individual dilakukan secara rutin, akan tetapi sebagian besar dilakukan dengan cara memanggil siswa yang bermasalah. Setiap kegiatan layanan konseling ditulis dalam laporan pelaksanaan konseling individual.

\section{PENUTUP}

Dalam layanan Bimbingan dan Konseling, konselor memiliki peran utama dan signifikan atas keberhasilan layanan bimbingan dan konseling. Konselor mempunyai tugas dan tanggungjawab terhadap peningkatan mutu dan pembaharuan kompetensi. Untuk menunjang pelaksanaan konseling, maka konselor dituntut untuk menguasai keterampilan konseling.

Pelaksanaan layanan konseling individual yang dilakukan di SMK 1 Kemlagi selama ini dilakukan secara rutin. Akan tetapi, layanan konseling lebih sering dilakukan dengan memanggil siswa yang bermasalah.

Agar proses konseling dapat berlansung dengan lancar dan mencapai tujuan yang diharapkan, maka konselor di SMK 1 Kemlagi sangat perlu untuk meningkatkan keterampilan-keterampilan dasar konseling.

\section{DAFTAR PUSTAKA}

Hariastuti, dkk. Keterampilan-Keterampilan Dasar dalam Konseling. Unesa University Press

Hartono \& Soedarmadji. (2013). Psikologi Konseling. Jakarta: Kencana Prenada Media Group

Hellen (2005). Bimbingan Dan Konseling. Jakarta: Quantum Teaching.

Holipah. (2011). The Using Of Individual Counseling Service to Improve Student's Learning Atitude And Habit At The Second Grade Student of SMP 
PGRI 6 Bandar Lampung (Journal Counseling)

Kusmaryani. (2010). Penguasaa

Keterampilan Konseling Guru Pembimbing di Yogyakarta. Jurnal kependidikan Volume 40, Nomor 2, November 2010 hal 175-188.

Mahadhita. (2015). Hubungan antara Ketrampilan Dasar Konseling (KDK) dengan Minat Siswa Mengikuti layanan konseling Individual di SMA Negeri Godog Tahun Ajaran 2014/2015. Universitas Negeri Semarang. (Skripsi)

Yusuf, S. (2009). Program Bimbingan \& Konseling Di Sekolah. Bandung: Rizqi Press 